\title{
Displaying dead bodies: bones and human biomatter post-genocide
}

Jessica Auchter University of Tennessee Chattanooga

Jessica-Auchter@utc.edu

\begin{abstract}
The after-effects of mass atrocity - bodies and bones - struggle to be defined within memorial projects. This article seeks to examine the politics at play in displaying dead bodies to interrogate the role of materiality in efforts to memorialise and raise awareness about on-going violences. It focusses on the nexus between evidence, dignity, humanity and memory to explore bone display in Rwanda. It then takes up two artistic projects that play on the materiality of human remains after atrocity: the art of Carl Michael von Hausswolff, who took ashes from an urn at the Majdanek concentration camp and used them as the material for his painting, and the One Million Bones Project, an installation that exhibits ceramic bones to raise awareness about global violence. In thinking about the intersections between human biomatter, art and politics, the article seeks to raise questions about both production and consumption: how bones and ashes of the dead are produced, and how they are consumed by viewers when placed on display in a variety of ways.
\end{abstract}

Key words: Bones, ashes, genocide, art

What is done to and with bodies and bones is more than ever a key question in the aftermath of violence in an era where political violence is most often materially enacted on bodies. The memorial art form has developed as an artistic response to mass death and atrocity, yet many consider memorials to be separate from artistic practice. To reckon with the horror of violence, such art struggles to deal with the beauty of the human body and figure, even in permanent repose, the coolness of human bone, and the same evidentiary value posed by these. The after-effects of mass atrocity - bodies and bones - thus struggle to be defined within memorial projects. This article seeks to examine the politics at play in displaying dead bodies and to interrogate the role of materiality in an effort to memorialise and raise awareness about on-going violence by exploring the way human biomatter is visually consumed as both memorial to and evidence of atrocity. The questions at issue, then: what are the international dimensions of the consumption of traumatic memory in an embodied way? How are bones constructed, produced, displayed and consumed? What role does the display of bones have in prompting a visceral 
response, and how is this co-opted, reinterpreted, reperformed, and reconstructed in international discourses?

By exploring the example of bones on display in genocide memorialisation, I seek to elucidate the politics of bodies as visceral representations of, and resistances to, state power. I focus on the nexus between evidence, dignity, humanity and memory to explore bone display in Rwanda. I also take up two artistic projects that play on the materiality of human remains after atrocity: the art of Carl Michael von Hausswolff, who took ashes from an urn at the Majdanek concentration camp that held the remains of Holocaust victims, and used them as the material for his painting, and the One Million Bones Project, an installation that exhibits ceramic bones to raise awareness about global violence, bringing to the fore issues of the production and consumption of bones. In thinking about the intersections between human biomatter, art and politics, these examples all raise questions about both production and consumption: how bones and ashes of the dead are produced, and how they are consumed by viewers when placed on display in a variety of ways. The article concludes by offering reflections on the ethical encounter with bones: the real bones of genocide victims that are part of the memorial art project, the constructed bones of the One Million Bones Project and the ashes that are themselves remains of remains - remains of bones - that have been turned into a medium for painting, asking after the politics of the display and viewing of human biomatter as it relates to mass atrocity.

I am less concerned about whether the display of human biomatter is humanising or dehumanising but rather with what cases of bone display tell us about how the production and consumption of the dead operate in global politics. That is, what is done with bodies and bones tells us how bone production and death more generally are envisioned, and how genocide and genocide memory are consumed in material ways. As a result, my focus is on the international dynamics of human biomatter, rather than the local dimensions. The case of the One Million Bones Project allows me to examine the politics of fabricating human remains, along with the dubious ethical considerations that underpin this. The Rwanda case allows me to focus on the politics of consuming these exhibitions in the context of genocide memorialisation in a museum setting.

\section{Displaying the dead: art out of ashes?}

To consider the display of dead bodies, one must engage with a long history of their display, from a medical context to that of memorialisation. In a time when memorialisation proliferates in a post-conflict setting, and legal frameworks to prosecute atrocity rely on forensic evidence, we are often asked to look at the dead body in a variety of contexts. What implications does this viewing have for these same frameworks? What does it mean to engage visually with human bones and, further, for bones to be used as the material symbol of atrocity? How are bones produced, displayed, consumed by Western audiences, and with what implications for the politics of memory? Do they humanise and dignify the dead, or render them inert, decontextualised commodities? And further, what stories do Western audiences tell 
themselves as they view these bones, and do these stories add to or subtract from a greater understanding of the dynamics of genocide and perceptions of the observer's role in raising awareness and humanitarian intervention?

This section probes these questions in order to elicit a methodology for approaching human biomatter on display. That is, it seeks to focus on theoretical framings of bodies in pain as a means of thinking about the questions of production and consumption of human biomatter that are the focus of the article. It does so using the case of Carl Michael von Hausswolff's paintings with ashes from the Majdanek concentration camp to intercede in these theoretical debates about dead body display.

The use of human biomatter in memorialisation is controversial. The notion that human remains are entitled to a certain form of dignity has historical roots. ${ }^{1}$ Indeed, Viscount Wolmer in a British House of Commons Debate in May 1920 noted, 'By all means have memorials. Make them out of government stone if you like. Make them uniform. But you have no right to employ, in making these memorials, the bodies of other people's relatives.' Although memorials are often also aesthetic projects, this aesthetic purpose is secondary to their memorial impetus. This section explores the aesthetic use of human remains in a context where the memorial impetus remained secondary, specifically the art of Carl Michael von Hausswolff, who made paintings using the ashes of concentration camps victims that he illicitly took from the Majdanek concentration camp memorial, as a way of drawing out some key arguments on the visual politics of human biomatter.

This discussion must begin with the body in pain. Much of the focus on human biomatter in art and in memorialisation has focussed on whether it is dehumanising. This debate is premised on the normative assumption that the dead body is entitled to particular forms of dignity, and that the suffering of others should not be on display. Elizabeth Dauphinee, for example, has addressed the way in which images of the body in pain, specifically the tortured bodies at Abu Ghraib, raise ethical questions about viewing and circulating such images. She argues that 'the act of witnessing others' pain (and deaths) is ... fraught with an unsayability, because the witness is limited to only a modicum of access to the trauma of the other body. ${ }^{3}$ This raises important questions about the purpose of displaying bodies. Her focus is on efforts to critique the regimes that made possible the torture of Abu Ghraib by recirculating the photographs, noting that the recirculation may in fact fetishise the body in pain. The same is true of much of the debate about the visual politics of the dead, both in the context of genocide memorialisation and the war on terror, as has been recently demonstrated. ${ }^{4}$

The visual encounter with the dead body is a troubling one because of the asymmetric relations of viewing: we look at the dead body, even while it cannot look back at us. As Rancière says, politics is that which renders visible that which has no right to be seen. ${ }^{5}$ The making visible of that which is usually considered taboo, dead bodies, is key to conceptualising the politics of genocide and its memorialisation, as well as a larger politics related to how we define awareness of atrocity issues. Yet, this focus on the question of dehumanisation tends to focus on a moral debate over display, rather than on how these displays are framed and consumed. Lauren Wilcox has noted in the context of suicide bombing how efforts to recover and resignify 
bodies can shed light on the construction of the state itself. ${ }^{6}$ Charlotte Heath-Kelly has described in detail the way the memorial project is a performance of resilience to efface mortality as a means of ensuring security. ${ }^{7}$ That is, both of these scholars call attention to the practices of power at play here. To some extent, this article places these two approaches in conversation with each other to consider how the display of bones is a political project involving the human body that can offer insights into the aesthetic politics of human biomatter and the politics of atrocity memorialisation. I now turn to one particular project that blurs the line between art and memorialisation, drawing out the theoretical framing of production and consumption of bones that will frame the rest of the article.

Carl Michael von Hausswolff visited the memorial at the concentration camp Majdanek in 1989 and, while there, took ashes from a large urn that forms part of the memorial site. In the urn is seven tons of a mixture of the ashes of those who died there and were cremated, and dirt: the pile of human remains was to be used by the Nazis as fertiliser. As the BBC notes, he decided not to use the remains at the time, because 'the material was too heavily loaded with the atrocities that had taken place at the site'. Still, in 2010 he 'decided to use the ashes mixed with water and describes figures appearing on the page "as if the ash contained energies or memories or 'souls' from people ... people tortured, tormented and murdered by other people in one of the 20th Century's most ruthless wars". 8

The painting, and its provenance, aroused resistance among some, particularly in the European Jewish community. Salomon Schulman, writing in a Swedish newspaper, described the painting as 'repulsive in the extreme', and went on to write 'who knows, some of the ashes might come from some of my relatives.' $\mathrm{He}$ continued, 'I will never go to this gallery and view it as the desecration of Jewish bodies ... I am sickened by his work and obsession with necrophilia.' ${ }^{10}$ There is some irony here, as necrophilia, defined as attraction to corpses, is one of the features that define the display of bodies, and even the ashes at Majdanek: audiences are consumers who interact with these human remains precisely because of their curiosity, or reverence, or whatever sentiment drives their desire to visit such a site.

Abraham Foxman, the head of the Anti-Defamation League, noted that 'it is outrageous that an artist would even consider using the ashes of living human beings in this manner ... the use of human remains as art is disrespectful and offensive, period.. ${ }^{11}$ The notion that the human body should not be utilised in particular ways is at odds with forms of memorialisation where the human body is on display. That is, as displays of bones and ashes act as memorials, they may also replicate the very logic of genocide by calling attention to the narrative of dehumanisation: the killing was so bad, so extraordinary, that ordinary logics of dead body display do not apply. Still, there seems to be a limit to this: while the body can be incorporated into certain types of memorial projects (the urn of ashes itself at Majdanek), many argue that it cannot or should not be incorporated into other types of projects. Although much of the media focus was on the theft of the ashes, as that was the portion of the act that may have involved criminal desecration of the dead, less attention was paid to analysing the larger question about how and when it is appropriate for human remains to be on display, and what this can tell us about how 
atrocity is memorialised and consumed by audiences in an era where we value memorialisation of mass violence.

After all, the painting was entitled Memory Works, bringing to the fore questions of appropriate memorialisation involving human remains. That is, von Hausswolff's project was designed to be a memorial of sorts, but to call attention to the aesthetic dimensions of human remains and violence, something that others have drawn attention to at Rwandan memorial sites: Philip Gourevitch, for example, has referred to dead bodies as beautiful: 'The randomness of their fallen forms, the strange tranquility of their rude exposure, the skull here, the arm bent in some uninterpretable gesture there - these things were beautiful.' ${ }^{12}$ Yet his points about beauty focus more on the material arrangement of the dead after genocide, rather than their affective status as human remains. Indeed, the way bodies are often displayed as evidence is conceived by its detractors as just as instrumentalising as von Hausswolff's use of human remains.

What the Hausswolff case demonstrates, then, is that human biomatter on display if often subject to debates centred on the idea of human dignity: appropriate display of remains is that which preserves its dignity, while unacceptable display is seen to violate the sanctity of the human body. Yet this focus on humanisation and dignity, while important, is a matter of interpretation, and elides the fact that bones are often consumed in particular ways based upon the way they are framed to the visitor. Von Hausswolff's project, framed as both art and memorial, is viewed differently than a display of the same human biomatter with a different framing. Bones have histories of production, and their display is designed to be consumed by viewers in particular ways. The remainder of the article seeks to trace this in specific cases in order to examine the effects of these mechanisms of production and consumption.

\section{The politics of human biomatter in Rwanda}

This section examines the way human biomatter becomes incorporated into genocide memorialisation. It does so by examining the case of the Rwandan genocide: literally an instance where nearly one million human beings disappeared, and human biomatter appeared in their place, raising ethical, practical, forensic and political issues. Much of this debate has focussed on whether bodies and bones should be displayed as a question of dignity, but I seek to focus instead on the politics of consuming these exhibitions in the context of genocide memorialisation. That is, I am less concerned with the reasons for the display than with what politics emerge from their display, and what understandings circulate about how dead bodies on display should be and are consumed in genocide memorialisation. As a result, I focus on the transnational and international dimensions of the consumption of genocide memorialisation rather than on the gravesite itself or the local dimensions of that memory, as others have discussed. ${ }^{13}$

Bodies and bones have a particularly strong role to play in Rwandan genocide memorialisation, ${ }^{14}$ which provides a useful case for interrogating the global politics of visibility because it is at the nexus of multiple competing and intersecting narratives at the international, national and local levels. In Rwanda, this is perhaps 
amplified even further in that literally hundreds of thousands of human beings simply disappeared, and unidentifiable bodies cropped up in their place, in churches, in fields, in rivers. Achille Mbembe characterises the Rwandan case: 'what is striking is the tension between the petrification of the bones and their strange coolness on one hand, and on the other, their stubborn will to mean, to signify something. ${ }^{15}$ That is, bodies are different than other forms of evidence in that they were once someone's loved ones; they blur the line between subject and object, and our social norms tell us that treating the dead body with dignity matters precisely because it is human, not thing, and it signifies something to us.

Bone display in Rwanda has emerged out of the competing impetuses of providing a dignified resting place for nearly one million sets of human remains, many of which were scattered and intermingled with one another, and providing visual evidence to guard against the spread of genocide ideology and inform the international visitor about Rwanda's past. Immediately after the genocide, in addition to the concerns about rebuilding state institutions, there was the more immediate matter of how to deal with the material remnants of the genocide. This included the numerous piles of bones along roadsides, inside and outside of churches and other buildings, and in fields that were traditionally used for subsistence farming. ${ }^{16}$ The task of rebuilding was thus at the outset a task of materially inscripting these bones into a story of what had happened, along with the notion that leaving the bodies in situ was undignified. This is particularly important given the Rwandans' historical traditions in terms of dead bodies that were largely centred on burial.

Yet there remained after the genocide a strong sense that visual evidence of a brutal genocide was necessary, both to legitimate certain policy narratives of the new Rwandan state and to connect Rwanda with larger global narratives about genocide and, specifically, prevention. The stark corporeality of human bones, especially when they bore the mark of machete strikes, was considered to be forensic evidence in international and national courts, and also simply representative of the larger genocide project. In the Rwandan case, then, the relevant question must begin from the base fact that the bones are there, that they exist in a very material sense, although their appearance is very much a political project. It is then a question of how these bones form a visceral display that moves between narratives of memorialisation and evidence, from the human body and its material framework as very much still human, redeemed through memorialisation, to wider conceptions of bodies and bones as evidence of genocide.

Bodies are displayed as a means to a larger end: the story of genocide memory itself. As Rachel Ibreck has detailed, bones in Rwanda are regarded as traces which can prevent forgetting and denial. ${ }^{17}$ Similarly, Jennie Burnet describes the way in which, for many survivors, burial of bodies by UNAMIR, the United Nations Assistance Mission for Rwanda, was perceived as part of an effort to cover up the evidence of the genocide. ${ }^{18}$ Paul Kagame's own words in 2001 gesture to the importance bodies have as evidence of the genocide: 'All these bodies that we just interred testify to what happened here and elsewhere all over the country.' ${ }^{19}$ As Ewa Domanska argues, the dead body acts both as evidence of a crime and as a reference point for the work of mourning. ${ }^{20}$ Dead bodies and bones, then, are the matter of genocide 
memorialisation in Rwanda. The bones are literally evidence of state power, and then how the display of bones constitutes an organisation, categorisation and rendering visible of bones so that they can be able to be logged into memory. That is, display of bones in the Rwandan context both humanises the bones by memorialising the material basics of human beings and memorialises a genocidal logic that renders human beings into bone by the means in which they are displayed. Yet this tension regarding dehumanisation is only one component of the display of the dead in Rwanda: the question also lingers about how visitors are instructed to engage with the dead.

When I was in Rwanda, conducting interviews for a previous book project, many of the survivors I spoke with seemed to have a sense that genocide denial was a pervasive issue, and thus that material evidence was the best, and indeed only, way of literally showing the world what had happened in an irrefutable manner. Thus a tension existed immediately after the genocide in trying to resolve the 'problem' of the dead body: whether to treat it according to traditional burial customs, or as a literal body of evidence. The fear of burial of many survivors is that 'with burial of their friends and relatives would come amnesia, indifference and the rewriting of history. ${ }^{21}$ Yet some critics of bones on display are concerned with how the human body is consumed visually and thus becomes an object of consumption. Michela Wrong tells of one of her friends who refers to the display of skulls and bones in Rwandan monuments as a form of necrophilia. ${ }^{22}$ There is thus the question of a perverse desire to look at the dead that is often considered taboo. As Philip Gourevitch says of his visit to Nyarubuye, a memorial where bodies are on display: "What to do? Look? Yes. I wanted to see them, I suppose; I had come to see them. ${ }^{, 23}$ This complex visuality speaks to the visceral response to viewing bodies. As Gourevitch says, when one looks at dead bodies, one does not leave with their experiences, but with the experience of looking at them. It is the visual consumption that characterises the relationship between the visitor and the dead body.

Gourevitch's point, and the one relevant to my argument here, is precisely that the visitor has come to look at the dead body. The relationship begins as one of the consumption of something which is not typically visually consumed. That is, what is on display is both the material remnants of a logic that created bare life, genocide itself, intended to make the visitor uncomfortable, and the memorial remnants of human individuals, a way to reorder traumatic memory into a form that can be consumed by memorial-site visitors. To some extent, then, when one visits a Rwandan memorial site where bones are on display the very design of the site instructs the visitor to engage with the body by consuming it as evidence. It is yet another piece of evidence in the exhibit, yet it is also accorded a sacred status, both as precious evidence and, paradoxically, as more-than-evidence. Therefore, the display here is very different from the way Uli Linke describes the Body Worlds exhibit, as dead bodies emptied of their historical markers and with their biographies of violence concealed. ${ }^{24}$ The dismembered corpse and the framing of evisceration often implies a fleshy being of some sort, a body part that invokes the partial body in its horror. The bone, however, implies the partial body in its essential material framework, emphasising not its disjuncture or dismemberment but, rather, its internal structure, often deemed to 
be a much less gory visual. Bones are interesting as the medium of display because any body can make bones. ${ }^{25}$ Indeed, every body makes bones out of itself eventually. Yet bones seem to be somehow representative of the body, in that the skeletal make-up recalls the human form in a significant way. Achille Mbembe refers to the production of skeletons in the Rwandan case: 'lifeless bodies are quickly reduced to the status of simple skeletons. Their morphology henceforth inscribes them in the register of undifferentiated generality: simple relics of an unburied pain, empty, meaningless corporealities, strange deposits plunged into cruel stupor. ${ }^{26}$ The notion that the skeleton is a more material or structural version of the body implies its status as a figure that can put into question particular structures that sustain international politics.

Rather than being gory visuals, in this case, the bones visually exhibit their violent histories through the physical effects of machete strikes and other harm, rendering them not simply commodities for consumption but a complex material representation of genocide and its victims. Similarly, the notion that it is strangers staring at them speaks to the asymmetric relationship inherent in viewing of this sort: the visitor to the mass grave is always a stranger, because it is impossible to know the mass grave and yet also visit it. The anonymous nature of the grave also emphasises the displacement of subjectivity replicated by the visit to the grave, by the reckoning with another's violent history even as the visitor is also forced to reckon with others' and her/his own material framework.

I do not intend to note here that the problem of mass death in Rwanda is only a material problem, as the project of Rwandan genocide memorialisation is a highly political one. The bones there are often utilised as political tools in the service of wider narratives. Yet the mechanism of this production, the social life of these remains, is elided in favour of a framing that instructs the viewer in particular ways of engaging with these sets of human remains. That is, there are two types of production at issue in the Rwandan case: first, the production of these bones through the killing of human beings, in 1994, where hundreds of thousands of dead bodies were produced. Second, these bones were reproduced when mass graves were unearthed in the early 2000s as a way of reckoning with the problem of memorialisation. Bodies were unearthed, bones were sorted, new mass graves were built and bones were placed on display. That is, this production was a political one, part of a broader politics of genocide memorialisation, as Laura Major has noted. ${ }^{27}$ Beyond this, the consumption of these bones by the visitor is carefully curated by these same social and political stories, even as the bones act in starkly material ways as evidence, as noted above.

\section{Bone production: one million 'bones'}

The politics of displaying bodies gets at the crux of what it means to be a politically qualified human being, one rendered visible. To explore this, I move to the One Million Bones Project, where the displays are of fabricated bones created out of clay, papier-mâché and other materials by school children, activists, political officials etc. As such, they are particularly interesting because they do not posit the 
same evidentiary value that human remains have, yet they raise important questions about the relationship between visibility and embodiment. They pose particularly interesting questions for the visual consumption of human biomatter because these bones are produced precisely so that they may be visually consumed: the making of bone facsimiles, the mode of production, is far from hidden to audiences of the project - they are the entire point.

The founders of the project often go into schools for the day to engage in a bonemaking and genocide education programme. The founder, Naomi Natale, an artist and activist, draws on her own experiences travelling around Africa, as well as a past project where she constructed and displayed hundreds of cribs in order to raise awareness of children dying of famine in the Horn of Africa. ${ }^{28}$ Her idea for the project drew on her knowledge of the Rwandan genocide, as well as the awareness that instances of genocide and atrocity were still happening around the world.

Natale wanted to make genocide relevant to Americans, so she came up with the One Million Bones Project in 2003. She draws on what Alison Landsberg has referred to as the politics of empathy: the idea that particular framings can position the viewer in ways that confront them with experiences outside the realm of their lived experience. By being forced to reckon with the experiences of another, viewers interpret these positionalities as meaningful. ${ }^{29}$ Natale focuses on the material component of this, so, rather than experiencing what another experiences, one encounters the shock and awe of the encounter with one's own mortality via one's own material framework. She says, 'I was thinking of a symbol that we could use that could attest to the gravity of this issue and could unite us. The only one that could do it justice is a bone. ${ }^{30}$ Rather than simply focussing on the power of bone as an image, she emphasises that the bones should be communally constructed, thereby raising community awareness.

At one school in Arizona, Natale, according to one of the teachers participating, showed students 'a pelvic "bone" she created after meeting a woman who had given birth to nine children, four of whom were killed. She related to this woman and used the bone to find a commonality, a human connection. ${ }^{31}$ The use of the quotation marks around the term bone, as if to exemplify the way in which the bones are supposed to mimic real human bones yet not approximate them, is interesting here. If they are not considered bones, then why display them as a means to raise awareness, to horrify the viewer into doing something by virtue of the significance of the display of bare bones? If they are not considered 'bones', do they raise the same ethical and political questions about displaying bones that Rwandan genocide memorialisation does, for example? And what kind of political act, besides simply raising awareness that dead bodies exist, does the project perform? As Elizabeth Dauphinee notes, 'the increasing reliance on visuality to tell us about the world creates a disconnect that makes possible the claim that this imagery can be circulated ethically. Indeed, it cannot be circulated ethically, even if we can identify our goals as in some way "ethical" '.32 That is, a project designed to cultivate empathy may not in fact do so.

The bones created out of clay are inscribed with messages, about genocide, or in honour of individuals who were victims of genocide. Natale exhibited one million 
of the bones in a 'mass grave' on the National Mall in Washington, DC in 2013. She is supported by a variety of groups, but also encourages donations for bones. The standard donation for someone who constructs a bone is $\$ 5$, and you can also donate $\$ 15$ and have a bone made for you. ${ }^{33}$ The funds raised will go to support organisations that aid displaced persons and raise genocide awareness. In addition to the display on the National Mall, some of the bones will be impregnated with seeds and later planted in gardens around the country. ${ }^{34}$ The main image of the project is an area where bones entirely cover the ground. A woman who is African in appearance walks blindfolded across the bones towards an African child who is also blindfolded, walking across the bones towards the woman.

The One Million Bones Project tries to make 206 bones per day, the number of bones in the human body. As Kamerick details, 'shelves in the offices are covered with clay recreations of ribs, hands, feet, skulls and other bones. ${ }^{35}$ News stories on the project frequently detail Natale hard at work making a bone resembling a child's femur or a woman's pelvic bone. They seem to normalise the construction and handling of bones. The idea of the project is to raise genocide awareness, because one million bones cannot be ignored. But this is questionable. In the case of Rwanda, one million individuals were ignored by the international community, and many more bones from their bodies are now buried in mass graves and displayed around the country. This notion of raising awareness relies on the idea that visibility is equated with agency, legitimacy, action and perhaps even being itself. Not only that, but it places the solution to this invisibility in the hands of the West, depicting the notion that if the West simply paid more attention to bones, genocide could be stopped.

There is something about the project that instrumentalises the body, since any body can make bones, in this instance even as an artistic project. It also normalises the handling and display of bones, to the extent that they simply appear on shelving in the project's office. Even the plan to plant the bones recalls the way in which, in many places where atrocity has been committed, bones have mingled with the ground and normal cycles of plant growth, as well as farmers planting over the bodies, have led to plants growing from bones. Yet there is a difference that seems to be elided by the project: the difference between clay bones and human bones that were once part of live human beings who were victims of a genocidal logic which rendered them simply bare bone on display.

An ethical question also arises. After all, the precise aim of genocide is itself to render bones visible by killing and dehumanising. What, then, is the implication of the purposeful rendering of clay bones visible as a mechanism of bringing awareness to genocide? Does it replicate the same logic of genocide? As Casper and Moore detail, 'bodies - seen and hidden, lost and found, alive and dead, actual and virtual bear the marks of power and the many local and global processes through which it produces subjects. ${ }^{36}$ This is just as true of the ceramic bones constructed by the One Million Bones Project as it is of the bones of Rwandan genocide victims displayed as part of their memorialisation. These two types of memorialisation both raise questions about why bones are displayed, what work they do in memorialisation and awareness, and ultimately what the ethics are of displaying human bones, or bones intended to approximate and represent human bones. 
The project renders bone a political tool by representing it exogenously from the context through which it was produced: it is only consumed, while the mechanisms of human bone production are elided. It should be noted here that the project is not obscuring the artistic production of bone representations but, rather, making its participants hyper-aware of it by utilising images of kilns and the production of the ceramic bones in its promotional material. By emphasising the construction of bones as an artistic project, it obscures the mechanisms by which real bones are created. By establishing an emotional link between the real bones in real mass graves and the manufactured bones that audiences touch, hold and bring into being, the focus shifts to very specific forms of bone production and consumption. The bones are intended to be consumed in a way similar to the real bones in real mass graves, but their production is hyper-visible, and thus the attention shifts from the way bones are produced through atrocity.

It seeks to make a statement about genocide prevention and awareness, yet it does so by exhibiting and representing bare life purposefully. It is not within the aims of this project to speculate about the moral rectitude of displaying bones in the Rwandan context, partly because the bones are already there and displaying them is one among other options that can be done with pre-existing bones, and partly because the project is one supported by many of the loved ones of those to whom the bones belonged. This is not to argue that the display of such bones is apolitical but, rather, that the politics of bones display must reckon with the material fact of bones, rather than producing them out of thin air: in the case of Rwanda, the bones are a very real result of the genocide itself. Approximately one million people disappeared, and stacks of bones appeared in their place. Yet the evidence apparent on the bones and sets of human remains is evidence of a very real genocide, and thus it is also a question of evidence on display. But in the One Million Bones Project, the bones are not pre-existing, and thus allow us to ask questions not simply about the politics of displaying bones, but about the politics of creating bones. Bones are generally created in the process of the death of the human being (or other live beings). When they are created outside of this context, they cannot simply be created in isolation, exogenously from the concerns and considerations of life and death itself and the politics that strips life to the bone. Indeed, imagery of the baking of bones in the kiln, depicted in promotional material on the One Million Bones Project website, recalls the process of baking bones in the oven crematoria during the Holocaust.

This is expressly the case in that the project simply displays piles of bones, disaggregated. It is not human remains on display, and the bones are not organised into shapes that resemble human beings. The bones are not evidence of a genocide. Rather than being death or victimhood on display, then, it is simply a pile of bones, bones without names. The issue of naming is a central one here, both in Rwandan genocide memorialisation and in the One Million Bones Project. After the Rwandan genocide, due to the large scale and nature of the deaths, identification has been a difficult if not impossible process, so much so that it has largely been given up.

This perhaps becomes an evidentiary problem. Bones on display at Rwandan memorial sites, while not without contestation, serve as evidence of genocide, and 
perhaps of a genocidal logic that renders human being into bare bone on display. But the One Million Bones Project creates bones, bones that are not evidence of a genocide and do not testify to its logic. That is, in Rwanda, bones, and the display of bones, are ways to reconfirm the physical, embodied base of evidence and anchor memory in a material way. But in the One Million Bones Project the original referent, human bone, is a phantom, even as its replica is on display. This is further reinforced by the fact that the bones on display in Rwandan memorials bear the scars of violence: they are damaged by the visual representation of a violent genocide that caused the death of the human beings to whom those bones belonged, for whom those bones are the only materiality left. But the bones of the One Million Bones Project are not broken, scarred, shattered. They are whole and thus there is nothing to tell us how these bones got here. They were not made in the destruction of a human being. They are not the material artefacts of genocide to be consumed in a memorial context. Yet they are still intended to be consumed by the international, and specifically the Western, spectator. But this consumption elides the very politics of bone production.

The issue of race and gender must be addressed here. Bones are deracialised and usually degendered, removed from their cultural, racial and gendered context, although bones and their measurement have in the past been the basis for racialised logics associated with claims to biological supremacy or inferiority. The everyday individual visitor cannot distinguish or determine the gender of bones, although there is something to be said for the emphasis on the construction of a more rounded pelvic bone indicative of a woman that recurs in the media coverage of the One Million Bones Project as a gendered subscript. That is, it must be noted that there are decisions about which bones will be created, and these decisions are a function of issues like race, class and age. In some ways the display of bones removes the extremely significant racialised element from the question of genocide and replicates the perpetuation of privileging of 'white death' via a geopolitical ordering of memory. ${ }^{37}$ This dilution of the ethnic and racialised component of genocide can be problematic for addressing it as a very specific form of violence, motivated by very specific perceived racial differences. This is further the case because classification based on bone (nose width, skull shape and size) was a key aspect of colonialist logic that led to the furtherance of ethnic divisions in Rwanda. Indeed, in Sam Kauffmann's short film documentary Massacre at Murambi, the narrator notes that one of the reasons often cited for non-intervention in Rwanda is that the victims were not white. In front of an image of the whitened bodies of Murambi and the white bones, the English subtitle of the narration appears, 'well, they're white now', ${ }^{38}$ an important commentary on the deracialisation of bones which is particularly relevant in light of the notion that in Rwanda, bones are displayed as a form of evidence of a racialised logic of genocide.

This section is not intended as a strict critique of the project but, rather, as an exploration of how certain bodies and bones become the purview of displays in the service of particular political stories. The awareness that the bones create is an awareness not simply of genocide and atrocity occurring around the world, but of the politics of displaying bodies and bones and the larger role of bones themselves 
in international politics. They call attention to the way international politics often instrumentalises bodies as merely the collateral damage of a violence which forms the central topic of examination for international relations. What the project contributes is a critical exploration not simply of the politics of display, but of the politics of the reduction of human life to bone itself. By normalising the making and display of bones, it in fact puts into question the normalisation of bone making and display in instances of atrocity. The project causes us to feel uneasy, rendering our own placements uncomfortable, and thereby more likely to be aware of displacements elsewhere. Rather than calling our attention to how the display of bones is horrifying, the One Million Bones Project calls attention to the way we are not disturbed by the display of bones, a fact which we find disturbing, thereby offering an opening for critical rethinking. If we are not horrified by the display of bones, yet perhaps, ethically we should be, then the awareness of our own lack of horror is itself horrifying and thus spurs the radical questioning of how we respond to bones and the processes in international politics (war, violence, conflict, famine) that render human beings into bones.

\section{Conclusions on the aesthetic politics of human biomatter}

This article has traced several ways that bones are displayed as a means to consider questions of production and consumption. The way we interact with bones matters because of the shared material framework: the bone invokes an embodied form of mimesis that evokes a visceral response. These responses are then co-opted by some of the awareness and artistic projects I have mentioned here, as ways to play on the politics of human bones, yet these projects bring up their own sets of questions about how human remains are mustered as both evidence and aesthetics. That is, each of these projects, even Rwandan genocide memorialisation, has its own politics. Memorialisation and awareness projects like the One Million Bones Project often claim to be separate from artistic considerations, but the way these projects are framed performs specific understandings about bones on display and invokes specific types of production and consumption. Bone display is often couched in terms of whether they humanise or dehumanise the victims of an atrocity, but this focusses on their effects rather than on the mechanisms of production and consumption.

Human biomatter is the material after-effect of atrocity, but it is also a material basis for drawing attention to issues of atrocity. Memorial sites and artistic projects generate benefits, but also raise questions about the larger industry that forms on the basis of mass atrocity. Traumatic memory is consumed in an embodied context, where the display of bones can provoke a visceral response. Yet this response is complex and political, and this article has argued that there is more to the discussion than simply the debate over whether bones should be displayed. Rather, this raises wider questions about how mass atrocity is visualised, co-opted, reinterpreted and reconstructed in local, national and international discourses. Although this contribution does not seek to provide answers to some of these questions, some conclusions can be drawn from the analysis here. First, the display of human biomatter is controversial because of the human element involved, yet it seems 
to be deemed more suitable in the context of memorialisation than in the context of artistic practice. Yet, the lines between art and memorialisation blur, as I have sought to demonstrate with the examples discussed. Second, if genocide and genocide memory are consumed in material ways, with bodies becoming increasingly important as evidence, do we need to rethink the ethics of engaging with the body in pain or the dead body? There may not be one ethical way of marking the destruction of the human body, and this may be a lingering dilemma that must be reckoned with.

\section{Notes}

1 J. Auchter, 'Corpses', in M. Salter (ed.), Making Things International I (Minneapolis, Minnesota, 2016).

2 J. Edkins, Missing: Persons and Politics (Ithaca, NY, Cornell University Press, 2011), p. 131.

3 E. Dauphinee, 'The Politics of the Body in Pain: Reading the Ethics of Imagery', Security Dialogue, 38:2 (2007), pp. 139-55, 142.

4 See J. Auchter, The Politics of Haunting and Memory in International Relations (London: Routledge, 2014), and T. Gregory, 'Dismembering the Dead,' European Journal of International Relations, 22: 4 (2016), 944-65.

5 Edkins, Missing, p. 7.

6 L. Wilcox, 'Explosive Bodies and Bounded States', International Feminist Journal of Politics, 16: 1 (2014), 66-85.

7 C. Heath-Kelly, Death and Security: Memory and Mortality at the Bombsite (Manchester, Manchester University Press, 2016). See also J. Auchter, The Politics of Haunting and Memory in International Relations (London, Routledge, 2014).

8 'Swedish Artist Uses Ashes from Holocaust Victims', BBC News, 6 December 2012, www.bbc.com/news/world-europe-20622289, accessed 13 February 2018.

9 E. Palmer, 'Carl Michael von Hausswolff's Stolen Holocaust Ashes Painting Probed', International Business Times, 9 January 2013, www.ibtimes.co.uk/holocaust-ashesconcentration-camp-painting-hausswolff-422298, accessed 13 February 2018.

10 M. Day, 'Swedish Artist Uses Jewish Holocaust Victims' Ashes for Painting', Telegraph, 5 December 2012, www.telegraph.co.uk/history/world-war-two/ 9723912/Swedish-artist-uses-Jewish-Holocaust-victims-ashes-for-painting. html, accessed 13 February 2018.

11 C. Siemazsko, 'Outrageous! Swedish Artist Causes Uproar by Using Ashes of Holocaust Victims to Make Painting', New York Daily News, 6 December 2012, www.nydailynews.com/news/world/artist-ashes-holocaust-victims-paintingarticle-1.1214909, accessed 13 February 2018.

12 P. Gourevitch, 'Among the Dead', in M. Roth and C. Salas (eds), Disturbing Remains (Los Angeles, The Getty Research Institute, 2001), 63-73, 66.

13 L. Major, 'Unearthing, Untangling, and Re-articulating Genocide Corpses in Rwanda', Critical African Studies, 7:2 (2015), 164-81.

14 And, as Erin Baines notes, in the genocide itself. See E. Baines, 'Body Politics and the Rwandan Crisis', Third World Quarterly, 24:3 (2003), 479-93, for an 
exploration of the human body as the surface upon which genocide as a nation-building process was inscribed.

15 A. Mbembe, 'Necropolitics', Public Culture, 15:1 (2003), 11-40, 35.

16 H. Cobban, Amnesty after Atrocity? Healing Nations after Genocide and War Crimes (London, Paradigm, 2006).

17 R. Ibreck, 'The Politics of Mourning: Survivor Contributions to Memorials in Post-Genocide Rwanda', Memory Studies, 3:4 (2010), 330-43.

18 J. Burnet, 'Whose Genocide? Whose Truth?' in A. Laban Hinton and K. O'Neill (eds), Genocide: Truth, Memory, and Representation (Durham, NC, Duke University Press, 2009), pp. 80-110, 96-97.

19 As cited in Burnet, 'Whose Genocide?'

20 E. Domanska, 'Towards the Archaeontology of the Dead Body', Rethinking History, 9:4 (2005), 389-413, 402.

21 M. Wrong, "It was sobering - but in a good way": Memorials for the Victims of Genocide in Rwanda Are Helping the Country's Reconciliation Process', Financial Times, 29 April 2006, p. 12.

22 Ibid.

23 Gourevitch, 'Among the Dead', 63.

24 U. Linke, 'The Limits of Empathy: Emotional Anesthesia and the Museum of Corpses in Post-Holocaust Germany', in A. Laban Hinton and K. O’Neill (eds), Genocide: Truth, Memory, and Representation (Durham, NC, Duke University Press, 2009), pp. 147-91.

25 S. Guyer, 'Rwanda’s Bones', Boundary, 2:36 (2009), 155-75, 159.

26 Mbembe, 'Necropolitics', 35.

27 Major, 'Unearthing, Untangling.

28 M. Kamerick, 'Artist, Activist Naomi Natale Embodies Passion to the Bone', New Mexico Business Weekly, 18 March 2011.

29 A. Landsberg, 'Memory, Empathy, and the Politics of Identification', International Journal of Politics, Culture, and Society, 22:2 (2009), 221-9.

30 Kamerick, 'Artist, Activist'.

31 R. Parker, 'Dobson Bones Project Raises Awareness About Genocide', The Arizona Republic, 30 April 2011, 16.

32 Dauphinee, 'The Politics of the Body in Pain', 148.

33 Kamerick, 'Artist, Activist'.

34 J. Mandeville, 'Making Change: One Million Bones Protests Genocide, One Papier-Mache Femur at a Time', Alibi, 19:13 (2010), https://alibi.com/art/31312/ Making-Change.html, accessed 1 March 2018.

35 Kamerick, 'Artist, Activist'.

36 Casper and Moore, Missing Bodies, 180.

37 I borrow the term 'white death' from K. Olds, J. Sidaway and M. Sparke, 'White Death', Environment and Planning D: Society and Space, 23 (2005), 475-9.

38 The documentary is available for viewing at www.youtube.com/watch? $\mathrm{v}=\_$T5bMehkUXQ, accessed 13 February 2018. 